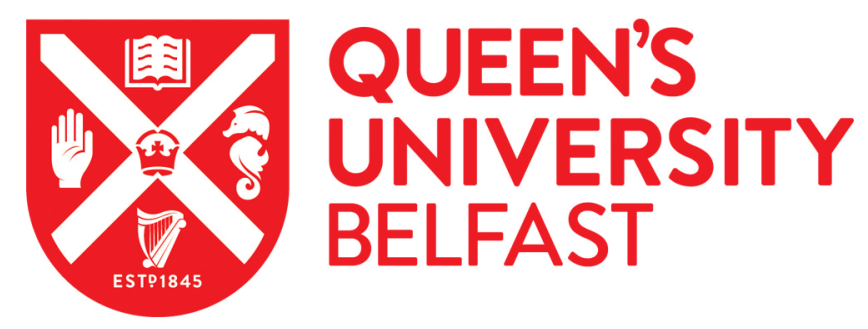

\title{
Water-Soluble Triarylborane Chromophores for One-and Two-Photon Excited Fluorescence Imaging of Mitochondria in Cells
}

Griesbeck, S., Zhang, Z., Gutmann, M., Luehmann, T., Edkins, R. M., Clermont, G., Lazar, A. N., Haehnel, M., Edkins, K., Eichhorn, A., Blanchard-Desce, M., Meinel, L., \& Marder, T. B. (2016). Water-Soluble Triarylborane Chromophores for One-and Two-Photon Excited Fluorescence Imaging of Mitochondria in Cells. Chemistry - $A$ European Journal, 22(41), 14701-14706. https://doi.org/10.1002/chem.201602639

Published in:

Chemistry - A European Journal

Document Version:

Peer reviewed version

Queen's University Belfast - Research Portal:

Link to publication record in Queen's University Belfast Research Portal

Publisher rights

Copyright 2016 Wiley-VCH Verlag GmbH \&Co. KGaA. This work is made available online in accordance with the publisher's policies. Please refer to any applicable terms of use of the publisher.

\section{General rights}

Copyright for the publications made accessible via the Queen's University Belfast Research Portal is retained by the author(s) and / or other copyright owners and it is a condition of accessing these publications that users recognise and abide by the legal requirements associated with these rights.

Take down policy

The Research Portal is Queen's institutional repository that provides access to Queen's research output. Every effort has been made to ensure that content in the Research Portal does not infringe any person's rights, or applicable UK laws. If you discover content in the Research Portal that you believe breaches copyright or violates any law, please contact openaccess@qub.ac.uk. 


\title{
Water-Soluble Triarylborane Chromophores for One- and Two- Photon Excited Fluorescence Imaging of Mitochondria in Cells
}

\author{
Stefanie Griesbeck, ${ }^{[a]}$ Zuolun Zhang, ${ }^{[a, b]}$ Marcus Gutmann, ${ }^{[c]}$ Tessa Lühmann, ${ }^{[c]}$ Robert M. Edkins, ${ }^{[a, d]}$ \\ Guillaume Clermont, ${ }^{[e]}$ Adina N. Lazar, ${ }^{[e]}$ Martin Haehnel, ${ }^{[a]}$ Katharina Edkins, ${ }^{[a, f]}$ Antonius Eichhorn, ${ }^{[a]}$ \\ Mireille Blanchard-Desce, ${ }^{*}{ }^{[e]}$ Lorenz Meinel, ${ }^{*[c]}$ Todd B. Marder ${ }^{*[a]}$
}

\begin{abstract}
Three water-soluble tetracationic quadrupolar chromophores comprising two three-coordinate boron $\pi$-acceptor groups bridged by thiophene-containing moieties were synthesised for biological imaging applications. The derivative 3 containing the bulkier $5-\left(3,5-\mathrm{Me}_{2} \mathrm{C}_{6} \mathrm{H}_{2}\right)-2,2^{\prime}-\left(\mathrm{C}_{4} \mathrm{H}_{2} \mathrm{~S}\right)_{2}-5^{\prime}-\left(3,5-\mathrm{Me}_{2} \mathrm{C}_{6} \mathrm{H}_{2}\right)$ bridge is stable over a long period of time, exhibits a high fluorescence quantum yield and strong one- (OPA) and two-photon absorption (TPA), with a TPA cross-section of $268 \mathrm{GM}$ at $800 \mathrm{~nm}$ in water. Confocal laser scanning fluorescence microscopy studies in live cells indicate localisation of the chromophore at the mitochondria; moreover, cytotoxicity measurements prove biocompatibilty. Thus, chromophore 3 has excellent potential for one- and two-photon excited fluorescence imaging of mitochondrial function in cells.
\end{abstract}

\section{Introduction}

Three-coordinate organoboron compounds have aroused much interest for various optical and electronic applications. ${ }^{[1]}$ Due to its vacant $p_{z}$-orbital, three-coordinate boron is a strong $\pi$-electron acceptor when connected to a conjugated $\pi$-system. The trigonal planar geometry and Lewis acidity of the boron atom facilitate

[a] S. Griesbeck, Dr. Z. Zhang, Dr. R. M. Edkins, Dr. M. Haehnel, Dr. K. Edkins, A. Eichhorn, Prof. Dr. T. B. Marder,

Institut für Anorganische Chemie

Julius-Maximilians-Universität Würzburg

Am Hubland, 97074 Würzburg (Germany)

E-mail: todd.marder@uni-wuerzburg.de

[b] Dr. Z. Zhang

State Key Laboratory of Supramolecular Structure and Materials College of Chemistry, Jilin University Changchun 130012 (China)

[c] M. Gutmann, Dr. T. Lühmann, Prof. Dr. L. Meine Institut für Pharmazie und Lebensmittelchemie . Iı liı ı-Maximilians-I Iniversität Würrhıı ırn attack by nucleophilies, resulting in bond cleavage or the formation of a four-coordinate boron species, which inhibits the boron atom from being part of the delocalised $\pi$-system. To prevent the attack of nucleophiles such as water, kinetic stabilisation can be achieved by introducing sterically demanding substituents, such as mesityl (Mes) or $2,4,6-\left(\mathrm{CF}_{3}\right)_{3} \mathrm{C}_{6} \mathrm{H}_{2}$ (FMes), ${ }^{[2]}$ to the boron atom, or by incorporation of the boron atom in a rigid, planar structure..$^{[3]}$ Only small anions, such as fluoride or cyanide, are able to overcome the steric bulk and attack the boron centre, which is exploited for anion-selective sensing. ${ }^{[4]}$ Triarylboranes are also used in organic light-emitting diodes (OLEDs) as electron-transporting, emitting and hole-blocking materials. ${ }^{[5]}$

The large change in dipole moment upon excitation of compounds including a triarylborane moiety as an electron acceptor results in large first and second-order molecular hyperpolarisabilities $\beta$ and $\gamma^{[6]}$ These interesting $2^{\text {nd }}$ and $3^{\text {rd }}$ order non-linear optical properties indicate that triarylboranes should be excellent components of chromophores that undergo two-photon absorption (TPA). Several octupolar and quadrupolar compounds using this boron acceptor were reported and their TPA crosssections $\left(\sigma_{2}\right)$ and fluorescence quantum yields $\left(\Phi_{\mathrm{f}}\right)$ were measured to develop structure-TPA relationships. ${ }^{[7]}$ In previous work, we reported that the insertion of thiophene rings into the $\pi$ bridge of $\mathrm{A}-\pi$-A chromophores ( $\mathrm{A}=$ boryl acceptor; here, $\mathrm{B}(\mathrm{Mes})_{2}$ ) results in a remarkable increase of the TPA crosssection, and synthesised a quadrupolar compound with a TPA cross-section of $1930 \mathrm{GM}$ at $770 \mathrm{~nm}$ that is, as far as we know, the highest $\sigma_{2} / \mathrm{m} . \mathrm{w}$. of all compounds containing $\mathrm{B}(\mathrm{Mes})_{2}$ and thiophene groups reported to date. ${ }^{[8]}$ Because the TPA maximum of each of these chromophores is located in the near-infrared (NIR) biological transparent window, the reported chromophores are potentially good candidates for two-photon excited fluorescence (TPEF) microscopy of living cells and tissues. However, these prototype compounds were not designed to be water-soluble, posing formidable challenges for in vitro or in vivo application, and it is this important aspect that we develop in this study while maintaining their aqueous stability and favourable optical properties.

Only a few examples of water-soluble triarylboranes have been reported to date. ${ }^{[9]}$ Gabbaï and co-workers achieved watersolubility by successively replacing the para-methyl groups of trimesitylborane with cationic ammonium substituents, and used two such compounds as efficient cyanide sensors in water. ${ }^{[10]}$ They and two other groups made use of a similar method for the preparation of water-soluble triarylboranes with phosphonium substituents for anion sensing. ${ }^{[11]}$ Recently, a water-soluble, nonionic triarylborane, containing polyethylene glycol chains as the hydrophilic groups, was reported by Yang and co-workers as an efficient fluorescence indicator for ATP in the cytoplasm and cell membrane. ${ }^{[12]}$ Furthermore, while our work was in progress, 


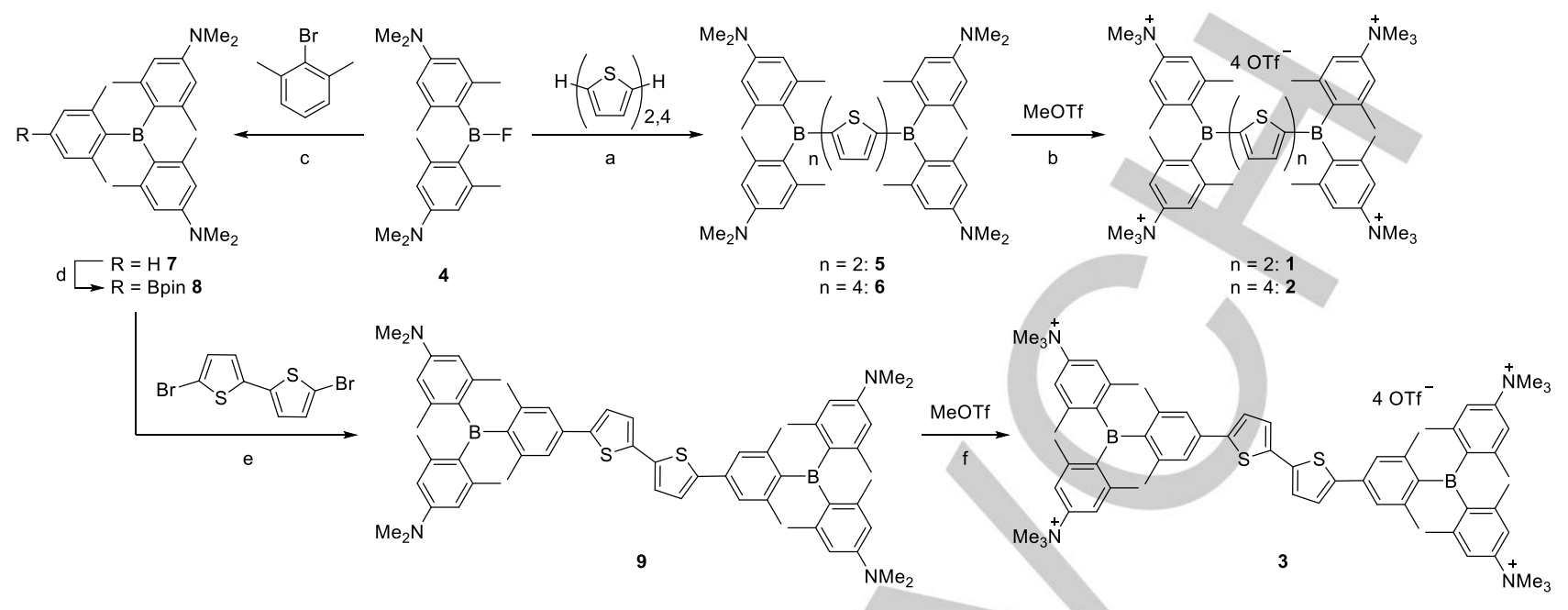

Scheme 1. Synthesis of the compounds 1-3. a) $n$-BuLi, THF, $-78{ }^{\circ} \mathrm{C}$ to r.t.; b) $\mathrm{CH}_{2} \mathrm{Cl}_{2}$, r.t.; c) $t$-BuLi, $\mathrm{THF},-78{ }^{\circ} \mathrm{C}$ to r.t.; d) $\mathrm{B}_{2}$ pin 2 , $[\mathrm{Ir}(\mu-\mathrm{OMe})(\mathrm{COD})]_{2}$, dtbpy, $\mathrm{THF}$ $80^{\circ} \mathrm{C}$; e) $\mathrm{Pd}_{2}(\mathrm{dba})_{3}$, SPhos, $\mathrm{KOH}$, toluene, $\mathrm{H}_{2} \mathrm{O}, 85^{\circ} \mathrm{C}$; f) $\mathrm{MeOTf}, \mathrm{CH}_{2} \mathrm{Cl}_{2} / \mathrm{Et}_{2} \mathrm{O} 1: 3$, r.t.

the same authors reported a water-soluble triarylborane containing $\mathrm{Cu}$ (II)-cyclen. While non-fluorescent itself, it can serve as a one- and two-photon excited fluorescence turn-on probe for $\mathrm{H}_{2} \mathrm{~S}$ at mitochondria. ${ }^{[13]}$

For TPEF imaging in biological systems, we prepared analogues of our previous quadrupolar compounds with trimethylammonium substituents for enhanced water-solubility. These substituents are not just promising due to their hydrophilic character, but are also expected to enhance the accumulation in the mitochondria. ${ }^{[14]}$ These features profile the molecules as potential sensors for the mitochondrial membrane potential, providing direct information about the status of a cell's power plants. ${ }^{[15]}$ Importantly, the use of such dyes, if amenable for TPA, is potentially beyond in vitro use on single cells, populations of cells, or united cell structures, but may very well expand into in vivo applications by virtue of the aforementioned accessibility of deeper cell layers and tissues for NIR light. Measurements of time-lapse acute mitochondrial responses to, e.g., drug exposure, inducible gene knock-in/-out or exposure to other challenges could provide immediate information on secondary respiratory challenges to mitochondria, thereby providing on-the-fly read-out of cell damage. Other potential applications include live cell imaging of diseased vs. healthy tissue, e.g., to understand the underlying mechanisms of dynamic transport in neurodegenerative diseases such as glaucoma ${ }^{[16]}$ or Alzheimer's disease. ${ }^{[17]}$

In this paper, we present three quadrupolar chromophores, 13, containing cationic triarylborane acceptors (Scheme 1). The $\pi$ bridge has been modified by the number of thiophene spacers and the nature of the aryl substituent adjacent to the boron atom. Their linear photophysical properties were examined experimentally and theoretically. With the water-stable derivative 3 we demonstrate herein one- and two-photon excited fluorescence imaging of the mitochondria in cells, due to its remarkable fluorescence quantum yield and high two-photon cross section in water. Co-localisation and cytotoxicity studies show that dye $\mathbf{3}$ is an excellent candidate for the use as a new mitochondrial imaging agent.

\section{Results and Discussion}

\section{Thiophene-boron directly connected chromophores 1 and 2}

Synthesis. The synthesis of the compounds $\mathbf{1}$ and 2 is summarised in Scheme 1. Compounds 5 and $\mathbf{6}$ were prepared via reaction of bis[4-(N,N-dimethylamino)-2,6-xylyl]fluoroborane $4^{[18]}$ with dilithiated bithiophene or quaterthiophene. Neutral compounds $\mathbf{5}$ and $\mathbf{6}$ were methylated with methyl triflate in $\mathrm{CH}_{2} \mathrm{Cl}_{2}$, and the products $\mathbf{1}$ and $\mathbf{2}$ precipitated in quantitative yield. Both compounds $\mathbf{1}$ and $\mathbf{2}$ were found to be water-soluble at concentrations suitable for fluorescence microscopy (Table 1), especially noting that commercially available chromophores for mitochondrial imaging are generally dissolved in dimethyl sulfoxide (DMSO).

Linear optical properties. The absorption and emission spectra of the methylated dyes $\mathbf{1}$ and $\mathbf{2}$ were measured in water (Fig. 1A) and MeCN (Figs. S30 and S31, see ESI). The absorption spectra recorded in water exhibit a broad band at $426 \mathrm{~nm}$ for compound 1 , whereas an elongated quaterthiophene $\pi$-system shifts the absorption by ca. $30 \mathrm{~nm}$ to the red for chromophore 2. The extinction coefficients, measured in $\mathrm{MeCN}$, due to enhanced stability (vide infra) and solubility, range from 28000 to $48000 \mathrm{M}^{-1} \mathrm{~cm}^{-1}$ (Table 1). The emission spectra are broad, with maxima spread over a ca. $150 \mathrm{~nm}$ range for the different compounds. The smaller quadrupolar compound, 1, has an emission maximum in water at $451 \mathrm{~nm}$, with a small Stokes shift of $1300 \mathrm{~cm}^{-1}$. By insertion of two more thiophene rings into the bridging unit, the emission of $\mathbf{2}$ is bathochromically 

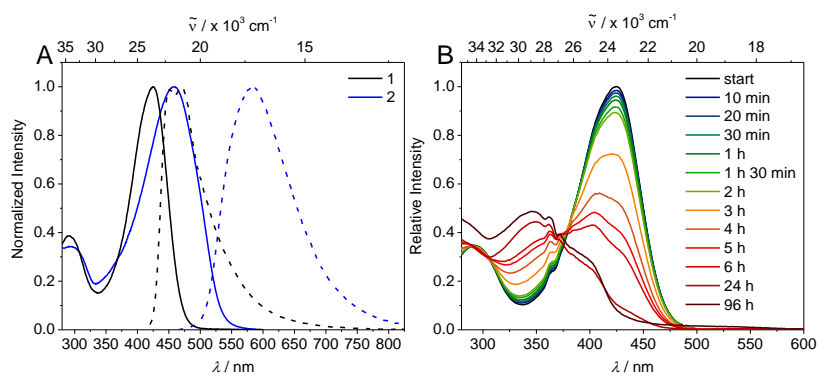

Figure 1. (A) Absorption (solid) and emission (dashed) spectra of 1 and 2 in water. (B) Absorption spectrum of 1 in water as a function of time.

shifted by more than $100 \mathrm{~nm}$, resulting in a much larger Stokes shift. The fluorescence quantum yields for $\mathbf{1}$ and $\mathbf{2}$ in water are remarkably large at 0.19 and 0.20 , respectively, whereas they are even larger in $\mathrm{MeCN}$, both being 0.41 . The fluorescence lifetimes are relatively short being 1.2 and $0.7 \mathrm{~ns}$ in water, respectively, and are similar in MeCN.

UV-vis absorption and emission spectra monitored over extended time periods demonstrate slow degradation of $\mathbf{1}$ and $\mathbf{2}$ in water as shown in Figs. 1B, S33, S38 and S39. Mass spectrometry of the degradation product confirmed hydrolysis at the boron centre. We note that light and oxygen speeds up the decomposition of 1 and 2 (Figs. S34-S37, S40-41 and S48).

\section{Water-stable chromophore 3}

Synthesis. To improve the water-stability of the chromophore for bioimaging applications, we synthesised compound $\mathbf{3}$ in which the additional two ortho-methyl groups provide significantly enhanced steric protection at the boron centre. Therefore, 4 was reacted with 2-lithio- $m$-xylene giving bis[4-( $N, N$-dimethylamino)-2,6-xylyl]2,6 -xylylborane, 7 in $63 \%$ isolated yield (Scheme 1). For use in Suzuki-Miyaura reactions, the para-position of this borane was borylated in an iridium-catalysed $\mathrm{CH}$-activation reaction in $91 \%$ isolated yield. ${ }^{[19]}$ Borylated species 8 was coupled with 5,5'dibromo-2,2'-bithiophene to prepare the neutral precursor 9 in $82 \%$ isolated yield, using $\operatorname{Pd}_{2}(\mathrm{dba})_{3}$ as the catalyst precursor, SPhos as the ligand and potassium hydroxide as the base.
Methylation of 9 was achieved with methyl triflate in $\mathrm{a}_{2} \mathrm{Cl}_{2} / \mathrm{Et}_{2} \mathrm{O}$ mixture giving a $76 \%$ isolated yield of $\mathbf{3}$. Compound $\mathbf{3}$ is air and moisture stable and can be stored on the bench as a solid at room temperature, in contrast to the commercially available MitoTrackers, for which storage at less than $-20^{\circ} \mathrm{C}$ and exclusion of light are recommended in their instructions. ${ }^{[20]}$ Chromophore 3 was also found to be water-soluble in the required concentration range.

Linear optical properties. The absorption maximum of $\mathbf{3}$ shifts hypsochromically to $425 \mathrm{~nm}$ in water, compared to 2 . This blue shift can be explained by somewhat diminished electronic delocalisation of the planar $\pi$-system to the boron $\mathrm{p}_{\mathrm{z}}$-orbital, as shown in TD-DFT calculations (Figs. S53-S55), as a result of increased twisting in the ground state due to the increased steric hindrance at the boron centre. The emission maximum is not affected as much as the absorption maximum; hence, the Stokes shift is further increased to $6000 \mathrm{~cm}^{-1}$. The fluorescence quantum yield of $\mathbf{3}$ in MeCN of 0.41 is the same as those of $\mathbf{1}$ and $\mathbf{2}$, whereas in water it is 0.10 which, while lower than the other two chromophores, is still remarkable. This decrease is a result of the ca. ten-times higher non-radiative decay rate in $\mathrm{H}_{2} \mathrm{O}$ compared to MeCN. While there is almost no difference between these two solvents for compounds $\mathbf{1}$ and $\mathbf{2}$, the lifetime is shortened drastically from $1.9 \mathrm{~ns}$ to 300 ps for $\mathbf{3}$ with increasing solvent polarity. Chromophore 3 shows almost no solvatochromism in its absorption spectra

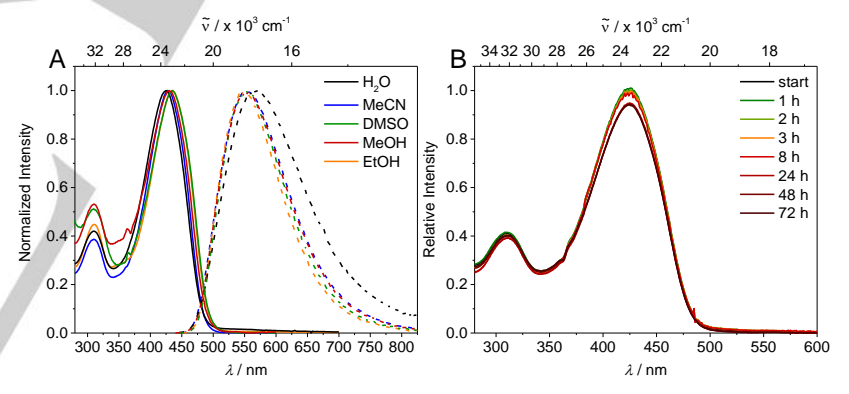

Figure 2. (A) Absorption (solid) and emission (dashed) spectra of $\mathbf{3}$ in different solvents. (B) Absorption spectra of $\mathbf{3}$ in water as a function of time.

Table 1. Photophysical data for chromophores 1, 2, 3 and MitoTracker Red CMXRos (MTRC).

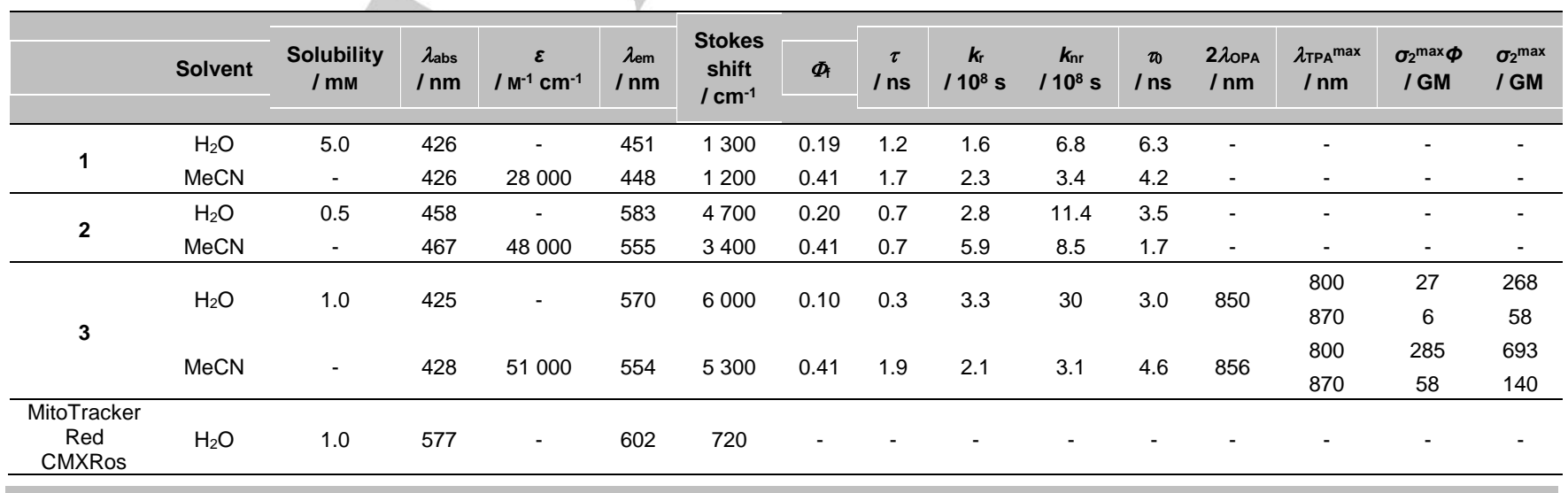


(Fig. 2A and Table S2). A progressive blue-shift of the emission is observed on going from water to (polar aprotic or protic) organic solvents of decreasing polarity. UV-vis measurements over $72 \mathrm{~h}$ clearly demonstrate that the increased steric protection provided by the additional methyl groups in $\mathbf{3}$ dramatically enhances stability in water (Fig. 2B). Furthermore, $\mathbf{3}$ is more stable in water than the commercially available imaging chromophore MitoTracker Red CMXRos (Figs. S46-S47).

\section{DFT calculations}

Density Functional Theory (DFT) calculations were carried out in order to examine the effects of the linker groups on the dihedral angles around the boron centre and its influence on conjugation. The geometry of each of the compounds 1-3 was optimised using DFT (B3LYP/6-31G*, gas phase). The structures all show the expected propeller arrangement of the aryl groups about the rigorously trigonal planar boron centre. The exchange of the thiendiyl linkers at the boron atom in $\mathbf{1}$ and $\mathbf{2}$ for xylylene groups in 3, leads to an increased twist of the aryl group with respect to the $\mathrm{BC}_{3}$ plane $\left(1: 16.2^{\circ} ; 2: 13.7^{\circ}\right.$; and $\left.3: 43.2^{\circ}\right)$. This reduced conjugation with the boron atom leads to the LUMO of 3 being $0.37 \mathrm{eV}$ higher in energy than that of 2 . The $\pi$-bridge backbone remains relatively planar in all cases (inter-ring dihedral angles 1:14.3 $3^{\circ}$ 2: 1.5 and $10.3^{\circ}$; and 3 : 18.9 and $12.4^{\circ}$ ).

Time Dependent-DFT (TD-DFT) calculations were carried out in order to obtain information on the nature of the optical transitions, and to compute the expected UV-vis absorption spectra of the compounds and compare this with the experimental spectra. TD-DFT calculations excellently reproduced the experimental absorption maxima of the lowest energy bands, the deviation in energy being within $0.02-0.15 \mathrm{eV}$ in simulated MeCN solution. Full details of these results and those in the gas phase are presented in the ESI (Figs. S53-S55). Introduction of the xylylene groups in $\mathbf{3}$ leads to a hypsochromically shifted absorption spectrum relative to 2 , in line with the experimental spectra. As seen in the natural transition orbitals (NTOs) (Figs. S53-S55) the $S_{1} \leftarrow S_{0}$ transitions of all three compounds contain a significant contribution from population of the empty boron $\mathrm{p}_{z^{-}}$ orbital, albeit that the transitions are predominantly $\pi-\pi^{*}$. The boron acceptor thus increases the conjugation length of the $\pi$ system. For TPA and TPEF applications, we also considered the $\mathrm{S}_{2} \leftarrow \mathrm{S}_{0}$ transition, as this is the lowest energy allowed TPA transition in a quadrupolar chromophore; thus, the NTOs for these transitions are plotted in Figs. S53-S55.

\section{Two-photon absorption}

Table 1 summarises the results of TPA measurements of chromophore 3 by using a two-photon excited fluorescence method. ${ }^{[21]}$ Due to the quantum selection rules for centrosymmetric molecules, the TPA maximum does not occur at the doubled wavelength of the one-photon absorption (OPA) maximum, but is located at a shorter wavelength. Indeed, as observed in Fig. 3, in which the TPA and rescaled OPA are compared, the maximum TPA is observed at higher energy, corresponding to an excited state which is not one-photon allowed. This is in agreement with the typical behavior of quadrupolar molecules. ${ }^{[22]}$ The lowest-excited state is, however, slightly OPA allowed (as indicated by the shoulder between 850 and $900 \mathrm{~nm}$ ), most probably due to conformational freedom responsible for slight deviations from ideal centrosymmetry.

It was not possible to determine the actual maximum of the TPA (Fig. 3), which is calculated to be at $792 \mathrm{~nm}$ (Table S8), as we have not measured beyond $800 \mathrm{~nm}$, but at $800 \mathrm{~nm}$, we observe a very large TPA cross section of $268 \mathrm{GM}$ in $\mathrm{H}_{2} \mathrm{O}$, which is increased to $693 \mathrm{GM}$ in MeCN (Fig. S49). This value is more than five times higher than that reported recently for the only other example of a triarylborane mitochondrial imaging chromophore (120 GM at $765 \mathrm{~nm}$ in DMSO). ${ }^{[13]}$ Due to the sizeable fluorescence quantum yields, relatively large values of the two-photon brightness (27 and $285 \mathrm{GM}$ in water and $\mathrm{MeCN}$, respectively) have been measured, making dye $\mathbf{3}$ of much promise for twophoton imaging in tissues.

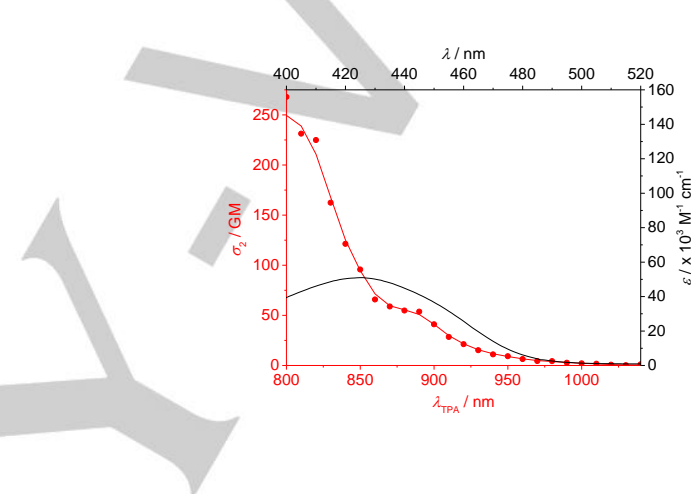

Figure 3. One-photon absorption (OPA) (black) and two-photon absorption (TPA) spectra (red) of $\mathbf{3}$ in $\mathrm{H}_{2} \mathrm{O}$.

\section{Cell cytotoxicity and live cell imaging}

In light of the above photophysical properties and water-stability of $\mathbf{3}$, and thus its potential as a chromophore for live cell imaging, we next examined its possible cytotoxicity in cells. Therefore, we exposed three different cell lines - murine-fibroblasts (NIH 3T3), human embryonal kidney (HEK 293T), and human-hepatic origin (HepG2-16) - to serial dilutions of $\mathbf{3}$ and also LiOTf and studied the cell metabolic activity with a colorimetric (WST-1) assay (Figs. 4 and S50-S52). These experiments confirmed that compound 3 did not influence the cell viability at concentrations as high as $10 \mu \mathrm{M}$. We have also checked the triflate counterion, as its lithium salt, for cytotoxicity and found that it showed no toxicity up to $100 \mu \mathrm{M}$ (for cytotoxicity results of 1 and $\mathbf{2}$, see ESI Figs. S50-S52). We therefore suggest that compound $\mathbf{3}$ can be safely used in live cell imaging applications and that this class of compounds shows potential for the development of in vivo diagnostics to probe mitochondrial function. 


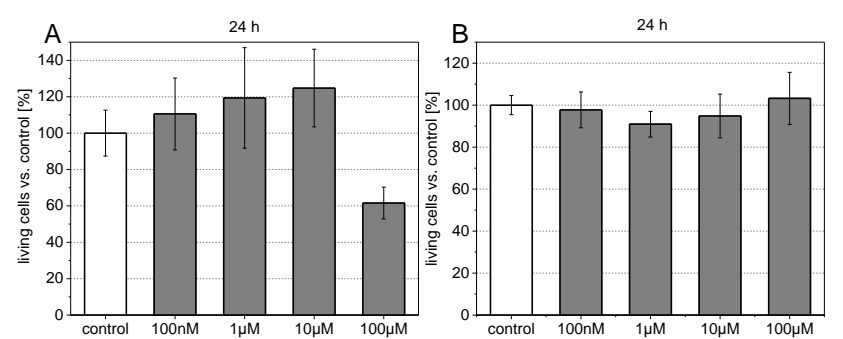

Figure 4. The metabolic activity of NIH 3 T3 cells was measured after $24 \mathrm{~h}$ with serial dilution of $\mathbf{3}(\mathrm{A})$ and LiOTf $(\mathrm{B})$ using a colorimetric assay. The results show the relative cell viability as a percentage of the untreated control (white bars) + the standard deviation.

Thus, living mouse embryo fibroblast cells (NIH 3T3) were treated with a $10 \mu \mathrm{M}$ concentration of chromophore 3 . Visualisation by confocal laser scanning fluorescence microscopy showed that 3 penetrated the cell membrane of living cells and localised at the mitochondria as confirmed by co-localisation experiments with the commercial mitochondrial imaging agent MitoTracker Red CMXRos (Fig. 5).

Figure 5. Confocal microscope live cell image of murine NIH 3T3 fibroblast cells with (A) $10 \mu \mathrm{M}$ of dye 3 and (B) $125 \mathrm{nM}$ of MitoTracker Red CMXRos. (C) Merged image indicating the co-localisation of compound $\mathbf{3}$ with mitochondria.

Figure 6. Confocal microscope image of POS 1 cells after $8 \mathrm{~h}$ of incubation with dye 3 (300 nm in the media): merge of transmission image (in grey) and fluorescence image (green) showing the internalisation of the dye within the cells: $(A)$ one-photon excitation ( $\lambda \mathrm{ex}=405 \mathrm{~nm}$; $\lambda \mathrm{em}=500-600 \mathrm{~nm}$ ) and $(B)$ twophoton excitation $(\lambda \mathrm{ex}=800 \mathrm{~nm} ; \lambda \mathrm{em}=500-600 \mathrm{~nm}) ;(C)$ emission spectrum upon one-photon excitation ( $\lambda \mathrm{ex}=405 \mathrm{~nm} ; 20 \mathrm{~nm}$ step) of the dye within the cell; (D) emission spectrum upon two-photon excitation ( $\lambda$ ex $=800 \mathrm{~nm} ; 20 \mathrm{~nm}$ step) of the dye within the cell.
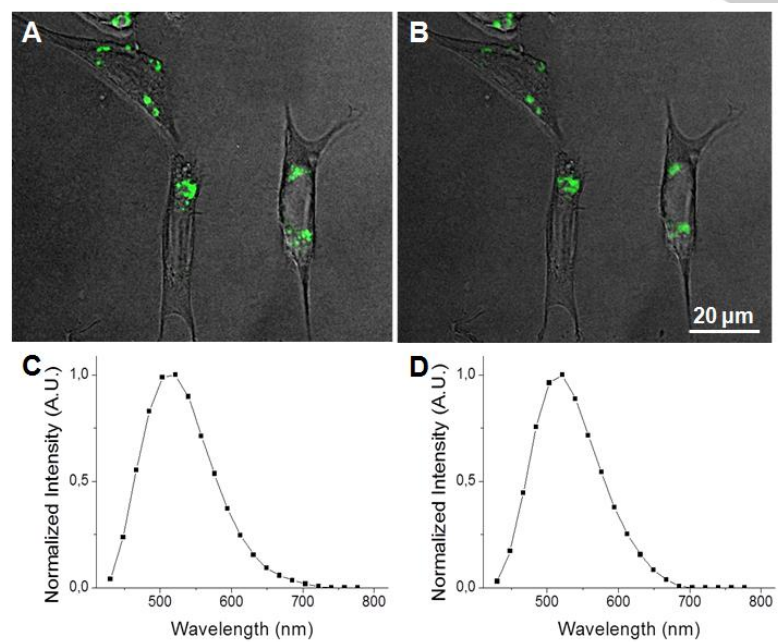

Based on the sizeable two-photon brightness of dye 3 in water, we also tested 3 as a two-photon dye to stain POS 1 cells - a cell line derived from an osteosarcoma tumour. The two-photon imaging experiments (and parallel confocal imaging under onephoton excitation) were performed using a $300 \mathrm{nM}$ concentration.
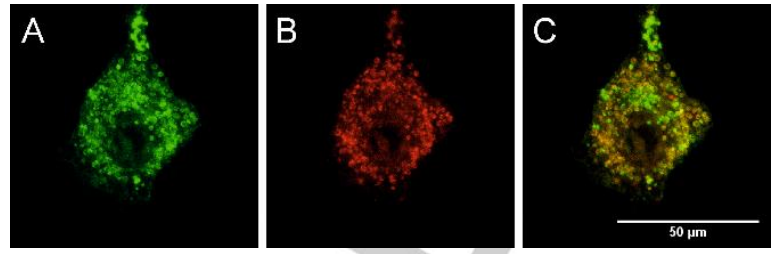

As clearly shown in Fig. 6, fluorescence images under standard one-photon and two-photon excitation show the same localisation of the dye. Furthermore, emission spectra of the uptaken dyes were acquired demonstrating that the dye structure is retained upon internalisation in the cells. Hence, the steric protection around the empty $p_{z}$-orbital at the boron atom not only confers stability of dye $\mathbf{3}$ in pure water, but is also sufficient to make it stable in a cellular environment. The blue-shifted emission compared to that observed in pure water can be related to environmental effects, suggesting that the dye is located in a less polar environment.

\section{Conclusions}

In conclusion, three water-soluble quadrupolar chromophores with triarylborane acceptors were synthesised. The two compounds 1 and 2 are bright emitters in water, but were shown to decompose, due to hydrolysis at the boron centre. In contrast, 3 has enough steric protection around the empty $p_{z}$-orbital at the boron atom that it is sufficiently stable in water. We have proved as well that $\mathbf{3}$ localises in mitochondria by co-localisation experiments, and that our new chromophore is not toxic at concentrations suitable for imaging purposes. We have shown that $\mathbf{3}$ is more stable than the commercial available MitoTracker Red CMXRos, while the solubility in water remains the same. We report here the first TPA cross-section measurement of a triarylborane in water, being $268 \mathrm{GM}$ at $800 \mathrm{~nm}$, which is very large; hence, $\mathbf{3}$ is suitable for two-photon live cell microscopy. We have reported herein a three-coordinate boron-containing chromophore for mitochondrial TPEF imaging, profiling this compound as a water-soluble, biocompatible mitochondrial tracker for in vitro live cell imaging applications. Future application as a diagnostic tool for clinical use should, in spite of the promising data set obtained with respect to (cellular) biocompatibility, be re-assessed in light of the outcome from robust (pre-)clinical safety studies. Optimisation of such chromophores to enhance quantum yields and TPA crosssections and to tune emission wavelengths is currently in progress.

\section{Acknowledgements}

T. B. M. is grateful for generous financial support from the Bavarian State Ministry of Science, Research, and the Arts for the Collaborative Research Network "Solar Technologies go Hybrid". Z.Z. and R.M.E. thank the Alexander von Humboldt Foundation for Postdoctoral Research Fellowships. R.M.E also thanks The Royal Commission for the Exhibition of 1851 for a research 
fellowship. M. B. D. is grateful for generous funding from the Région Aquitaine (chair of excellence). This study has also been carried out with financial support from the French State, managed by the French National Research Agency (ANR) in the frame of "the Investments for the future" Programme IdEx Bordeaux LAPHIA (ANR-10-IDEX-03-02). The two-photon microscopy was carried out at the Bordeaux Imaging Center, a service unit of the CNRS-INSERM and Bordeaux University, a member of the national infrastructure France Biolmaging. Financial support by Deutsche Forschungs-gemeinschaft (DFG; ME - 3820/3-1) is gratefully acknowledged by L. M.

Keywords: borane $\bullet$ luminescence $\bullet$ two-photon excited fluorescence $\cdot$ mitochondrion $\cdot$ cell imaging

[1] a) C. D. Entwistle, T. B. Marder, Angew. Chem. Int. Ed. 2002, 41, 2927 2931; b) C. D. Entwistle, T. B. Marder, Chem. Mater. 2004, 16, 4574 4585; c) S. Yamaguchi, A. Wakamiya, Pure Appl. Chem. 2006, 78, 14131424; d) F. Jäkle, Coord. Chem. Rev. 2006, 250, 1107-1121; e) F. Jäkle, Chem. Rev. 2010, 110, 3985-4022; f) Z. M. Hudson, S. Wang, Dalton Trans. 2011, 40, 7805-7816.

[2] Z. Zhang, R. M. Edkins, J. Nitsch, K. Fucke, A. Steffen, L. E. Longobardi, D. W. Stephan, C. Lambert, T. B. Marder, Chem. Sci. 2015, 6, 308-321.

[3] Z. Zhou, A. Wakamiya, T. Kushida, S. Yamaguchi, J. Am. Chem. Soc. 2012, 134, 4529-4532.

[4] a) T. W. Hudnall, C.-W. Chiu, F. P. Gabbaï, Acc. Chem. Res. 2009, 42, 388-397; b) Z. M. Hudson, S. Wang, Acc. Chem. Res. 2009, 42, 1584 1596; c) C. R. Wade, A. E. J. Broomsgrove, S. Aldridge, F. P. Gabbaï, Chem. Rev. 2010, 110, 3958-3984; d) E. Galbraith, T. D. James, Chem. Soc. Rev. 2010, 39, 3831-3842.

[5] a) T. Noda, Y. Shirota, J. Am. Chem. Soc. 1998, 120, 9714-9715; b) Y. Shirota, H. Kageyama, Chem. Rev. 2007, 107, 953-1010; c) F. Li, W. Jia S. Wang, Y. Zhao, Z.-H. Lu, J. Appl. Phys. 2008, 103, 034509-1-034509 6; d) C. Sun, Z. M. Hudson, M. G. Helander, Z.-H. Lu, S. Wang, Organometallics 2011, 30, 5552-5555; e) A. Shuto, T. Kushida, T. Fukushima, H. Kaji, S. Yamaguchi, Org. Lett. 2013, 15, 6234-6237.

[6] a) Z. Yuan, N. J. Taylor, T. B. Marder, I. D. Williams, S. K. Kurtz, L.-T. Cheng, J. Chem. Soc., Chem. Commun. 1990, 21, 1489-1492; b) Z. Yuan, N. J. Taylor, R. Ramachandran, T. B. Marder, Appl. Organomet Chem. 1996, 10, 305-316; c) C. Branger, M. Lequan, R. M. Lequan, M. Barzoukas, A. Fort, J. Mater. Chem. 1996, 6, 555-558; d) Z. Yuan, C. D. Entwistle, J. C. Collings, D. Albesa-Jové, A. S. Batsanov, J. A. K. Howard, N. J. Taylor, H. M. Kaiser, D. E. Kaufmann, S.-Y. Poon, W.-Y. Wong, C. Jardin, S. Fathallah, A. Boucekkine, J.-F. Halet, T. B. Marder, Chem. Eur. J. 2006, 12, 2758-2771.

[7] a) Z.-Q. Liu, Q. Fang, D. Wang, G. Xue, W.-T. Yu, Z.-S. Shao, M.-H. Jiang, Chem. Commun. 2002, 23, 2900-2901; b) Z.-Q. Liu, Q. Fang, D. Wang, D.-X. Cao, G. Xue, W.-T. Yu, H. Lei, Chem. Eur. J. 2003, 9, 50745084; c) Z.-Q. Liu, Q. Fang, D.-X. Cao, D. Wang, G.-B. Xu, Org. Lett. 2004, 6, 2933-2936; d) Z.-Q. Liu, M. Shi, F.-Y. Li, Q. Fang, Z.-H. Chen, T. Yi, C.-H. Huang, Org. Lett. 2005, 7, 5481-5484; e) L. Ji, Q. Fang, M.-
S. Yuan, Z.-Q. Liu, Y.-X. Shen, H.-F. Chen, Org. Lett. 2010, 12, 5192 5195; f) Y. Chen, G.-Q. Liu, Y.-Y. Wang, P. Yu, Z. Liu, Q. Fang, Synth Met. 2012, 162, 291-295; g) N. S. Makarov, S. Mukhopadhyay, K. Yesudas, J.-L. Brédas, J. W. Perry, A. Pron, M. Kivala, K. Müllen, J. Phys. Chem A 2012, 116, 3781-3793; h) M. Charlot, L. Porrès, C. D. Entwistle, A. Beeby, T. B. Marder, M. Blanchard-Desce, Phys. Chem. Chem. Phys. 2005, 7, 600-606; i) C. D. Entwistle, J. C. Collings, A. Steffen, L.-O. Pålsson, A. Beeby, D. Albesa-Jové, J. M. Burke, A. S. Batsanov, J. A. K. Howard, J. A. Mosely, S.-Y. Poon, W.-Y. Wong, F. Ibersiene, S. Fathallah, A. Boucekkine, J.-F. Halet, T. B. Marder, J. Mater. Chem. 2009, 19, 7532-7544; j) J. C. Collings, S.-Y. Poon, C. Le Droumaguet, M. Charlot, C. Katan, L.-O. Pålsson, A. Beeby, J. A. Mosely, H. M. Kaiser, D. Kaufmann, W.-Y. Wong, M. Blanchard-Desce, T. B. Marder, Chem. Eur. J. 2009, 15, 198-208.

[8] L. Ji, R. M. Edkins, L. J. Sewell, A. Beeby, A. S. Batsanov, K. Fucke, M. Drafz, J. A. K. Howard, O. Moutounet, F. lbersiene, A. Boucekkine, E. Furet, Z. Liu, J.-F. Halet, C. Katan, T. B. Marder, Chem. Eur. J. 2014, 20 , 13618-13635.

[9] a) H. Zhao, L. A. Leamer, F. P. Gabbaï, Dalton Trans. 2013, 42, 8164 8178; b) T. W. Hudnall, F. P. Gabbaï, J. Am. Chem. Soc. 2007, 129, 11978-11986.

[10] C.-W. Chiu, Y. Kim, F. P. Gabbaï, J. Am. Chem. Soc. 2009, 131, 60-61.

[11] a) Y. Kim, F. P. Gabbaï, J. Am. Chem. Soc. 2009, 131, 3363-3369; b) T. Agou, M. Sekine, J. Kobayashi, T. Kawashima, Chem. Eur. J. 2009, 15, 5056-5062; c) K. C. Song, K. M. Lee, N. V. Nghia, W. Y. Sung, Y. Do, M. H. Lee, Organometallics 2013, 32, 817-823.

[12] X. Li, X. Guo, L. Cao, Z. Xun, S. Wang, S. Li, Y. Li, G. Yang, Angew. Chem. Int. Ed. 2014, 53, 7809-7813.

[13] J. Liu, X. Guo, R. Hu, X. Liu, S. Wang, S. Li, Y. Li, G. Yang, Anal. Chem 2016, 88, 1052-1057.

[14] a) X. Zhao, Y. Li, D. Jin, Y. Xing, X. Yan, L. Chen, Chem. Commun. 2015, 51, 11721-11724; b) M. Grzybowski, E. Glodkowska-Mrowka, V. Hugues, W. Brutkowski, M. Blanchard-Desce, D. T. Gryko, Chem. Eur. J. 2015, 21, 9101-9110; c) N. Jiang, J. Fan, F. Xu, X. Peng, H. Mu, J. Wang, X. Xiong, Angew. Chem. Int. Ed. 2015, 54, 2510-2514; d) M. Homma, Y. Takei, A. Murata, T. Inoue, S. Takeoka, Chem. Commun. 2015, 51, 6194-6197.

[15] S. W. Perry, J. P. Norman, J. Barbieri, E. B. Brown, H. A. Gelbard, BioTechniques 2011, 50, 98-115.

[16] Y. Takihara, M. Inatani, K. Eto, T. Inoue, A. Kreymerman, S. Miyake, S. Ueno, M. Nagaya, A. Nakanishi, K. Iwao, Y. Takamura, H. Sakamoto, K. Satoh, M. Kondo, T. Sakamoto, J. L. Goldberg, J. Nabekura, H. Tanihara, Proc. Natl. Acad. Sci. USA 2015, 112, 10515-10520.

[17] Z.-H. Sheng, Q. Cai, Nat. Rev. Neurosci. 2012, 13, 77-93.

[18] C.-W. Chiu, F. P. Gabbaï, Organometallics 2008, 27, 1657-1659.

[19] I. A. I. Mkhalid, J. H. Barnard, T. B. Marder, J. M. Murphy, J. F. Hartwig, Chem. Rev. 2010, 110, 890-931.

[20] Molecular Probes, Inc., WP 07510, Eugene, 2008

[21] a) C. Xu, W. W. Webb, J. Opt. Soc. Am. B 1996, 13, 481-491; b) M. A. Albota, C. Xu, W. W. Webb, Appl. Opt. 1998, 37, 7352-7356.

[22] M. Barzoukas, M. Blanchard-Desce, J. Chem. Phys. 2000, 113, 39513959. 
Entry for the Table of Contents (Please choose one layout)

Layout 1:

\section{FULL PAPER}

Text for Table of Contents

Layout 2:

\section{FULL PAPER}

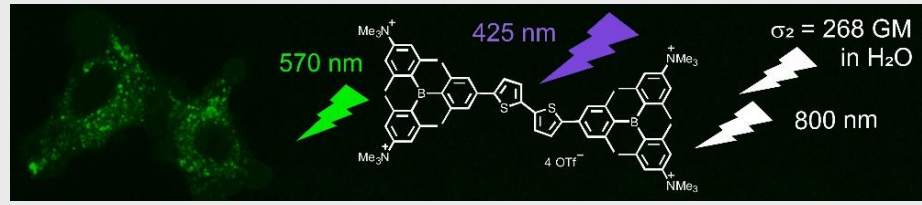

Very positive image of boron: A new tetracationic quadrupolar 3-coordinate boron compound is water-soluble and stable, and has a large two-photon absorption cross section and fluorescence quantum yield, even in water. It localises at mitochondria and is non-toxic to cells at concentrations required for one- and two-photon excited fluorescence imaging of mitochondrial function.
Author(s), Corresponding Author(s)*

Page No. - Page No.

Title

((Insert TOC Graphic here: $\max$. width: $5.5 \mathrm{~cm}$; max. height: $5.0 \mathrm{~cm}$ ))
Stefanie Griesbeck, Zuolun Zhang, Marcus Gutmann, Tessa Lühmann, Robert M. Edkins, Guillaume Clermont, Adina N. Lazar, Martin Haehnel, Katharina Edkins, Antonius Eichhorn, Mireille Blanchard-Desce, ${ }^{*}$ Lorenz Meinel, * Todd B. Marder*

Page No. - Page No.

Water-Soluble Triarylborane Chromophores for One- and TwoPhoton Excited Fluorescence Imanina of Mitnohnndria in Colle 